\title{
Measurements of total ozone amount over Badajoz (Southwestern Spain) by means of a GUV multiband radiometer
}

\section{Medidas de la cantidad total de ozono sobre Badajoz (suroeste de España) mediante un radiómetro multicanal GUV}

\author{
J. A. Bogeat $\left(1,{ }^{*}\right)$ A. A. Piedehierro(1), A. Serrano(1), M. L. Cancillo(1), \\ M. A. Obregón(1), R. Benítez(2) \\ 1. Department of Physics, University of Extremadura, Spain. \\ 2. Department of Mathematics, University of Extremadura, Spain. \\ (*) Email: bogeat@unex.es \\ Recibido / Received: 30/01/2011. Aceptado / Accepted: 30/08/2011.
}

\begin{abstract}
:
This paper presents the first measurements of total ozone amount performed at the radiometric station of Badajoz (Spain) by means of a multichannel radiometer GUV-2511. The retrieval of total ozone amount from GUV measurements of solar ultraviolet irradiance is performed with the support of look-up tables calculated using the SBDART radiation transfer code. This methodology is based on the different absorption by ozone suffered by the radiation at two certain near wavelengths. In this case the pair 305, $340 \mathrm{~nm}$ was chosen because of its better performance than the pair 305, $320 \mathrm{~nm}$. The look-up table contains the ratio between irradiances at the mentioned wavelengths calculated under different theoretical conditions of solar zenith angle and total ozone amount. The estimations of actual total ozone amount are calculated applying the look-up table to the experimental irradiance ratios as measured by the GUV radiometer. In order to validate these estimations, they are compared with the values provided by the OMI (Ozone Monitoring Instrument) aboard NASA EOS/Aura satellite during April 2010. Results indicate a general good agreement between both datasets, showing a notable dependence with the cloudiness conditions.
\end{abstract}

Keywords: Ozone, UV Radiation, Multichannel Radiometer.

\section{RESUMEN:}

En este trabajo se presentan las primeras medidas de cantidad total de ozono realizadas en la estación radiométrica de Badajoz mediante un radiómetro multicanal GUV-2511. La obtención de la cantidad total de ozono a partir de medidas de irradiancia solar ultravioleta se realiza con la ayuda de tablas "look-up" calculadas utilizando el código de transferencia radiativa SBDART. Esta metodología se basa en la diferente absorción por ozono sufrida por la radiación en ciertas longitudes de onda próximas. En este caso se eligió el par 305, $340 \mathrm{~nm}$ porque funciona mejor que el par 305, $320 \mathrm{~nm}$. La tabla "look-up" contiene los cocientes entre la irradiancias a las longitudes de onda mencionadas, calculadas bajo diferentes condiciones teóricas del ángulo cenital solar y de la cantidad total de ozono. Las estimaciones de la cantidad total de ozono real se calculan aplicando la tabla "look-up" a los cocientes de irradiancias medidos experimentalmente por el radiómetro GUV. Para validar estas estimaciones, se compararon con los valores proporcionados durante abril de 2010 por el instrumento OMI (instrumento para la monitorización del ozono) que está a bordo del satélite EOS/Aura de la NASA. Los resultados indican un acuerdo general bueno entre ambos conjuntos de datos, mostrando una dependencia notable con las condiciones de nubosidad.

Palabras clave: Ozono, Radiación UV, Radiómetro Multicanal. 


\section{REFERENCIAS Y ENLACES / REFERENCES AND LINKS}

[1.] High Speed Ground-based Ultraviolet Radiometer, User's Manual, Biospherical Instrument Inc. Technical Report (2003).

[2]. A. Tanskanen, N. A. Krotkov, J. R. Herman, A. Arola, "Surface ultraviolet irradiance from OMI", IEEE T. Geosci. Remote 44, 1267-1274 (2006).

[3]. P. Richiazzi, S. Yang, C. Gautier, D. Sowle, "SBDART: A research and teaching software tool for planeparallel radiative transfer in the Earth's atmosphere”, Bull. Amer. Meteor. Soc. 79, 2101-2114(1998).

[4]. CMP11 Instruction Manual, Kipp\&Zonen, Technical Report. Manual version 1007 (2010).

[5]. A. Dahlback, "Measurements of biologically effective UV doses, total ozone abundances, and cloud effects with multichannel, moderate bandwidth filter instruments", Appl. Opt. 35, 6514-6521 (1996).

[6]. K. Stamnes, J. Slusser, M. Bowen, "Derivation of total ozone and cloud effects from spectral irradiance measurements", Appl. Opt. 30, 4418-4426 (1991).

[7]. A. Pettazzi, J. A. Souto, "Medidas operativas derivadas de un radiómetro GUV2511 multirango", XXIX Jornadas Científicas de la Asociación Meteorológica Española, Pamplona, Spain, 24-26 de Abril (2006).

[8]. M. Al-Riahi, N. Hamdani, K. Tahir. "Contribution to the study of the solar radiation climate of the Baghdad environment", Sol. Energy 44, 7-12 (1990).

\section{Introduction}

The key role of stratospheric ozone as the main absorber for the ultraviolet solar radiation has brought a high interest in its continuous monitoring all throughout the world. This importance has been even emphasized during the last two decades due to the decrease in ozone caused by the anthropogenic emission of CFC gases. Nowadays the emission of these gases has been almost ceased, but the recovery of stratospheric ozone up to 1980s values will not be reached before 2070 .

In this framework, reliable and very precise measurements of ozone are demanded. For this task multi-band radiometers such as the GUV2511 [1] constitute an interesting instrumentation. These radiometers present some favorable characteristics with respect to other instruments, such as their relatively low cost and ease to operate and calibrate, which facilitate their general acquisition and use at many radiometric stations.

This study presents the first estimations of total ozone obtained from GUV measurements at the radiometric station of Badajoz (Spain) and the validation by their comparison with the total ozone amount provided by the Ozone Monitoring Instrument (OMI) [2] aboard the EOS/Aura satellite.

\section{Data}

First measurements performed by the GUV-2511 [1] multiband radiometer of the radiometric station of Badajoz (Spain) are presented. This instrument has been manufactured by Biospherical Instruments Inc. It consists of a sixchannel temperature controlled sensor of ultraviolet radiation that measures horizontal global irradiance with narrow bandwidth (10 $\mathrm{nm}$ ) centred at 305, 313, 320, 340, 380 and 395 $\mathrm{nm}$ and their respective offset values are $7.2 \times 10^{-7}, \quad-1.6 \times 10^{-7}, \quad-2.8 \times 10^{-7}, \quad 1.6 \times 10^{-7}$, $6.6 \times 10^{-7}$ and $-7.2 \times 10^{-8} \mathrm{~W} /\left(\mathrm{m}^{2} \mathrm{~nm}\right)$. A seventh channel measures photosynthetically active radiation (PAR). The cosine error is less than $5 \%$ from $0^{\circ}$ to $70^{\circ}$ and $\pm 10 \%$ from $71^{\circ}$ to $85^{\circ}$. This radiometer has been recently installed on the terrace of the Physics Department of the University of Extremadura in Badajoz (38 $52^{\prime}$ $58^{\prime \prime} N, 7^{\circ} 06^{\prime} 25^{\prime \prime} W, 199 \mathrm{~m}$ a.s.l.). The period of study extends from 10th to 20th April 2010. Along this period measurements were sampled every second and averaged every minute obtaining significant final values at one-minute frequency.

In order to analyze the effect of cloudiness on the estimation of ozone, solar global irradiance was measured by a Kipp\&Zonen CMP11 pyranometer [4] located near the GUV instrument at the station. Measurements were registered every one-minute in a Campbell Scientific data-logger. The CMP11 pyranometer was calibrated in the intercomparison campaign 
held at "El Arenosillo" Atmospheric Sounding Station belonging to the National Institute of Aerospace Technique (INTA) in September 2009. In this campaign it was calibrated by comparison to a reference instrument which had been previously calibrated at the World Radiation Center in Davos (Switzerland).

On the other hand, simultaneous total ozone amount as estimated by the Ozone Monitoring Instrument were obtained from the NASA web site. The OMI radiometer is on board the NASA EOS/Aura satellite and provides estimations of total zone amount at a frequency of one or two estimations a day for each location. These estimations are available at ftp://toms.gsfc.nasa.gov/pub/omi/data/. The satellite overpasses the station between 12 and 15 UTC every day. The OMI estimations correspond to the value integrated in an area of $13 \times 24 \mathrm{Km}$. The instrument has a relative accuracy error of $3 \%$ in its ozone amount estimations. [2].

\section{Methods}

The algorithm to estimate the total ozone amount followed the methodology proposed by Dalhback [5], Stamnes [6] and Pettazzi and Souto [7] for a multi-channel radiometer. According to this methodology, the ozone is estimated based on its different effect on two nearby wavelengths with very different absorption by ozone. Several authors suggested using the pair of wavelengths 305 and $320 \mathrm{~nm}$, or 305 and $340 \mathrm{~nm}$, being all of them available in the GUV-2511. [1]

Obtaining the amount of ozone requires additional support from a radiative transfer model. In our case the SBDART (Santa Barbara Disorted Atmospheric Radiative Transfer) [3] was used. These calculations were done considering cloudless sky, background stratospheric aerosol with optical thickness of 0.01 and tropospheric aerosols rural type. Thus, simulations of the irradiance reaching at ground level at 305, 320 and $340 \mathrm{~nm}$ for different conditions of ozone amount and solar zenith angle were performed. For these simulations ozone amount ranged from $200 \mathrm{DU}$ to $500 \mathrm{DU}$ by $5 \mathrm{DU}$ steps, and the solar zenith angle from $0^{\circ}$ to $60^{\circ}$ by $1^{\circ}$. Values corresponding to the ratio between the irradiance at 305 and $320 \mathrm{~nm}$, and between the irradiance at 305 and $340 \mathrm{~nm}$ for each value of ozone amount and solar zenith angle were summarized in a look-up table. Petazzi and Souto [7] recommend the use of the channel $340 \mathrm{~nm}$ better than $320 \mathrm{~nm}$ since the former is less affected by ozone than the latter. According to them, the pair $305,340 \mathrm{~nm}$ has been used.

Once the look-up table was built, the total ozone amount was calculated according to them using the GUV-2511 measurements. These retrieved values were subsequently compared to the simultaneous total ozone amount estimated by the OMI satellite instrument for the location of the Badajoz station.

In order to account for the effect of the cloudiness on the ozone estimations, the clearness index $k t$ [8] has been calculated. This index is calculated as the ratio between the solar irradiance measured at the earth's surface and the downward solar irradiance at the top of the atmosphere.

\section{Results and discussion}

Figure 1 shows the ozone amount estimated by GUV and OMI. Measurements performed between 12 and 15 UTC are represented since they approximately correspond to the satellite overpass time at the station. Instantaneous values between 12 and 15 UTC and their corresponding average values are shown for each day of the period of study.

The results show a general good agreement between the GUV and OMI estimations of total ozone amount. Although the overall behaviour is suitably described by both instruments, it is worth to note that this agreement is worse for the central days of the period of study, when the variability of the estimated values by GUV instrument is also higher. In these cases the GUV seems to overestimate the OMI values. 


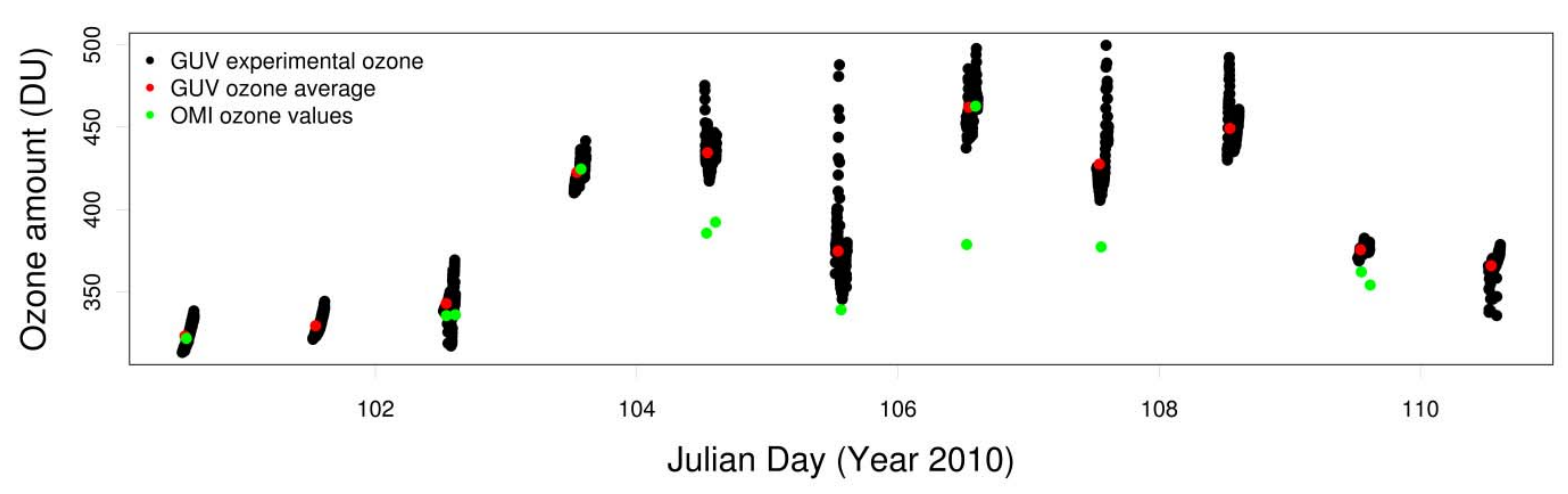

Fig. 1. Temporal evolution of total ozone amount estimations by GUV and OMI.

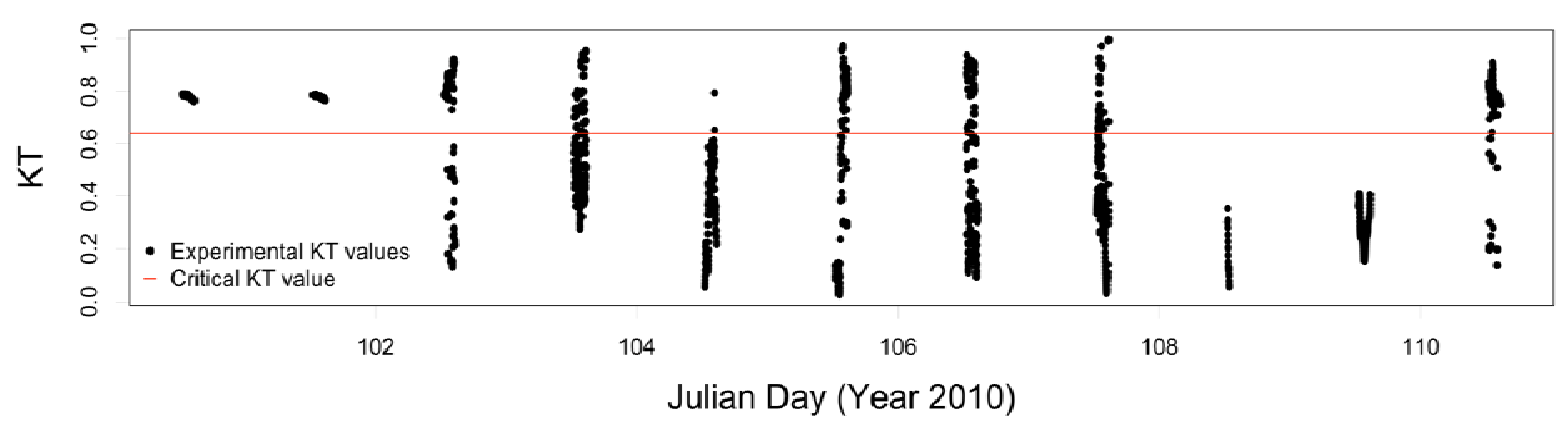

Fig. 2. Evolution of KT values.

Table I.

Comparison results.

\begin{tabular}{|c|c|c|c|c|c|c|c|c|c|c|c|}
\hline Day & 100 & 101 & 102 & 103 & 104 & 105 & 106 & 107 & 108 & 109 & 110 \\
\hline OMI ozone (DU) & 322 & - & 336 & 425 & 389 & 339 & 421 & 377 & - & 358 & - \\
\hline GUV ozone average (DU) & 323 & 330 & 343 & 423 & 435 & 375 & 462 & 428 & 449 & 376 & 366 \\
\hline GUV standard deviation (DU) & 7 & 6 & 10 & 7 & 11 & 25 & 12 & 20 & 13 & 3 & 8 \\
\hline Relative difference (\%) & 0.4 & - & 2.1 & 0.5 & 11.7 & 10.5 & 9.8 & 13.3 & - & 4.9 & - \\
\hline
\end{tabular}

In order to assess the effect of cloudiness on the comparison of values, the clearness index was calculated and represented in Fig. 2. According to this index, the first two days (days 100 and 101) correspond to cloud-free conditions with a rather uniform clearness index along the day and an average value about 0.7. Then, after the noon of the third day (day 102), the cloudiness appears, resulting in a high variability of the clearness index. In the central days, partially cloudy conditions with frequent focalisation phenomena lead to alternating extremely high and low values. During the days 104, 108 and 109 overcast conditions predominate.

Table I gives the ozone daily values estimated by both methods. The GUV value for each day is obtained as the average of 180 data in the interval from 12 to $15 \mathrm{UTC}$. Also shown are their standard deviations and the relative differences between GUV and OMI estimations (GUV$\mathrm{OMI}$ /OMI. One can observe that there is a very good agreement between the results for a clear day (100) and confirm that the highest values of the relative difference between both estimations correspond to the days 104 to 107.

The results indicate that GUV overestimates the total ozone amount under partially cloudy conditions and overcast conditions. In general this issue could be related to the overall net effect of attenuation of ultraviolet radiation by clouds. However, in these cases, the effect of cloudiness on the radiation reaching the ground is rather complex and highly depends on the spatial distribution of the clouds. In some cases the focalisation phenomena can increase the 
irradiance measured at ground up to values even higher than those measured at the top of the atmosphere.

\section{Conclusions}

In this paper the performance of the estimation of the total ozone amount from ultraviolet irradiance measurements provided by a GUV2511 multichannel radiometer has been assessed. The GUV estimations were compared with satellite OMI estimations resulting in a general good agreement in spite of the high variability of ozone values showed in these days (values ranged between 320 DU and $460 \mathrm{DU}$ ). This agreement is really good for cloud-free conditions while an overall overestimation is found under cloudy conditions. This study positively contributes to a better understanding of the effect of the cloudiness in the estimation of total ozone amount by radiation measurements performed from satellite and ground level.

\section{Acknowledgements.}

This work is partially supported by the research projects CGL2008-05939-C03-02/CLI, CTM2008-03114-E and CGL2011-29921-C02-01 granted by the Spanish Ministerio de Ciencia e Innovación. M. A. Obregón and A. A. Piedehierro thank the Junta de Extremadura for their grants. Special thanks are due to Michael Holas from Biospherical Instruments Inc. for his valuable help. 